\title{
Dysfunkcje narządu przedsionkowego u dzieci
}

\author{
Vestibular Disorders in Children
}

\author{
Przemysław Śpiewak * (D), Ewa Zamysłowska- Szmytke** (D)Michalina Śpiewak ***(D) \\ *Poradnia Audiologiczno -Foniatryczna NZOZ Audiofonika Bielsko- Biała \\ **Klinika Audiologii i Foniatrii Instytutu Medycyny Pracy im Prof. Jerzego Nofera w Łodzi \\ ${ }^{* * *}$ Studenckie Koło Naukowe przy Zakładzie Dermatologii Eksperymentalnej UJ w Krakowie opiekun Prof. Dr. Hab. Radosław \\ Śpiewak \\ DOI:10.20966/chn.2020.58.457
}

\section{STRESZCZENIE}

Celem pracy jest próba znalezienia zależności pomiędzy uszkodzeniami narządu przedsionkowego u dzieci, a występowaniem objawów w postaci: zawrotów głowy i zaburzeń równowagi. Zachowanie równowagi wymaga sprawnych odruchów: przedsionkowo -ocznego i przedsionkowo-rdzeniowego. W wieku rozwojowym symptomatologia uszkodzeń błędnika będzie zależała od tego na jakim etapie rozwoju do takiego uszkodzenia dojdzie. Pacjenci z wrodzoną wadą przedsionka z reguły nie uskarżają się na zawroty głowy. Dominującym objawem u nich jest opóźnienie rozwoju sprawności motorycznych, co zazwyczaj nie jest wiązane przez lekarzy z dysfunkcją błędnika. Oczopląs samoistny jako objaw ostrego uszkodzenia przedsionka pojawia się u niemowląt i małych dzieci rzadziej niż u pacjentów starszych. Oczopląs u młodszych dzieci ma w większości przypadków charakter ukryty. Natomiast częstość występowania zawrotów głowy i zaburzeń równowagi u dzieci i młodzieży, w zależności od przyjętych definicji tych objawów, szacuje się na poziomie od $0,4 \%$ do $5,7 \%$ badanej populacji. Główną przyczyną napadowych zawrotów głowy u dzieci jest migrena i zespoły z nią związane. Sprawność błędnika można szacować próbami: fotela obrotowego, dwukaloryczną, VHIT oraz VEMP. Wszystkie testy przedsionkowe, za wyjątkiem obrotowej, wymagają minimum współpracy ze strony pacjenta. Wniosek: Niezmiernie rzadko udaje się potwierdzić, że objaw określany przez dziecko jako zawrót głowy jest spowodowany trwałym uszkodzeniem błędnika.

Słowa kluczowe: uszkodzenie przedsionka, zawroty głowy, dzieci, oczopląs, VHIT

\section{ABSTRACT}

The aim of the article is an attempt to find a parallel relationship between injuries of the congenital inner ear (vestibular) disorder in children and the occurrence of symptoms in the form of dizziness and vertigo. Balance requires efficient reflexes: vestibule-ocular reflex and vestibule-spinal reflex. At developmental age the symptomatology of vestibular damage depends on the stage of development at which such damage occurs. Patients with congenital vestibular disorder usually do not report any dizziness. Their dominant symptom is manifested in delayed motor skills development which is usually not associated by the doctors with vestibular disorder. Spontaneous nystagmus as a symptom of acute vestibular damage occurs less frequently in infants and young children than in older patients. Nystagmus in younger children, in most cases, is latent. However, the incidence of dizziness and vertigo in children and adolescents, depending on the adopted definitions of these symptoms, is estimated at $0.4 \%$ to $5.7 \%$ of the studied population. The main cause of paroxysmal dizziness and vertigo in children is migraine associated symptoms (MAS). The vestibule's functional efficiency can be estimated with the following tests: Damped rotational chair test, Caloric nystagmus test, VHIT- Video Head Impulse Test, and VEMP - Vestibular Evoked Myogenic Potentials test. All the vestibular tests, with the exception of rotational test, require minimum cooperation from the patient. In extremely rare cases it is possible to confirm that the symptom described by the child as dizziness is caused by permanent vestibular disorder.

Key words: vestibular disorders, vertigo, dizziness, children, nystagmus, Video Head Impulse Test- VHIT
Nieprawidłowy i opóźniony rozwój motoryczny dziecka może być skutkiem, a zarazem jedynym dostrzegalnym dla lekarza objawem uszkodzenia błędnika ucha wewnętrznego (zwanego także przedsionkiem). Dlatego w diagnostyce różnicowej nieprawidłowego rozwoju motorycznego u dzieci należy zawsze uwzględniać wady i choroby przedsionka. W badaniach dzieci z zawrotami głowy i zaburzeniami równowagi próbuje się korzystać z metod stosowanych w neurootologii pacjentów dorosłych. Niestety, ze względu na odrębną symptomatologię oraz ograniczone możliwości badań aparaturowych u młodszych dzieci, często nie udaje się rozpoznać przyczyn ich dolegliwości.

Celem niniejszej pracy jest przedstawienie aktualnego stanu wiedzy na temat odrębności i problemów diagnostyki zawrotów głowy i zaburzeń równowagi u dzieci na podstawie danych literaturowych oraz własnych doświadczeń w badaniu najmłodszych pacjentów w Poradni Audiologicznej.

\section{WSTĘP}

Zachowanie równowagi jest złożonym procesem wymagającym scalenia informacji $\mathrm{z}$ wielu narząów zmysłów, przede wszystkim wzroku, czucia głębokiego oraz przedsionka zwanego także błędnikiem. Dobra orientacja przestrzenna i równowaga wymaga spójnych informacji docierających z tych narządów do analizatorów w ośrodkowym układzie nerwowym. Błędnik informuje o ruchu i zmianach położenia głowy. Jest on receptorem wyzwala- 
jącym odruchy które umożliwiają zachowanie równowagi. Odruchy te można w uproszczeniu podzielić na:

1. Odruch przedsionkowo-oczny (vestibulo-ocular reflex, VOR), dla którego efektorem są mięśnie ruchowe gałki ocznej.

2. Odruch szyjno-oczny (cervico-ocular reflex, COR)

Oba wymienione odruchy umożliwiają ufiksowanie obrazu na siatkówce oka przy zmianach położenia głowy, przy czym COR pełni prawdopodobnie funkcję pomocniczą i jego znaczenie rośnie w przypadku uszkodzeń błędnika.

3. Odruchy przedsionkowo-rdzeniowe (vestibulo-spinal reflexes, VSR) warunkujące utrzymanie postawy ciała podczas ruchu głowy w dwóch wymiarach: pionowym i poziomym (kompensacja zmian prędkości kątowej i liniowej). Odruchem wspomagającym jest tu odruch przedsionkowo-szyjny (vestibulo-cervical reflex, VCR), którego łuk kończy się w mięśniu mostkowo- obojczykowo -sutkowym.

W przypadku dysfunkcji błędnika występują objawy subiektywne w postaci złudzenia ruchu (określanego jako zawrót głowy) oraz objawy obiektywne, takie jak oczopląs i niemożność utrzymania równowagi. Dojrzewanie odruchów przedsionkowych warunkuje rozwój kontroli posturalnej i zdolności do zachowania równowagi [1].

Do początku XIX wieku błędnik z jego częścią przedsionkową, woreczkiem i łagiewką oraz kanały półkoliste uważano za część narządu słuchu. W 1824 roku Flourens zademonstrował, że uszkodzenie kanału półkolistego gołębia spowodowało oczopląs i wymusiło zmianę położenia głowy [2]. Pod koniec XIX w. Ewald starał się wyjaśnić procesy kompensacji uszkodzeń przedsionka u gołębi [3]. Badania eksperymentalne Magnusa w latach dwudziestych XX w. na królikach i kotach wyjaśniły wpływ uszkodzeń błędnika na odruch toniczny szyi. Magnus jako pierwszy opisał w 1924 r. asymetryczny toniczny odruch szyjny u ludzi [4]. W latach 1944 i 1952 Andrè-Thomas stwierdził, że badanie odruchów „tonicznego szyjnego” i „,błędnikowego odruchu prostowania", może być przydatne w diagnostyce dzieci z chorobami układu nerwowego [5]. Cohen i Suzuki wykazali wpływ elektrycznej stymulacji nerwów ampukkowych poszczególnych kanałów półkolistych na ułożenie głowy i tułowia oraz indukowanie oczopląsu [6]. W 1965 roku Twitchel zaprezentował $\mathrm{w}$ badaniach na małpach wpływ obustronnej deprywacji przedsionkowej i wzrokowej na odruchy postawy [7]. W 1981 roku Kaga i wsp. za pomocą fotela obrotowego wykazali u dzieci ilościową zależność pomiędzy wrodzonymi wadami przedsionka a rozwojem sprawności motorycznych i zachowania równowagi [8]. Odruchy przedsionkowe warunkujące prawidłową postawę ciała są powszechnie stosowane w terapii uszkodzeń ośrodkowego układu nerwowego. Stymulację przedsionkową wykorzystuje się w treningach tzw. ,integracji zmysłowej". W 1972 roku Ayers wprowadziła w USA stymulację przedsionkową do rehabilitacji dzieci autystycznych i pacjentów mających poważne trudności w nauce szkolnej [9]. Te metody terapeutyczne nie są jednak z reguły poprzedzane diagnostyką przedsionkową.

\section{EPIDEMIOLOGIA I SYMPTOMATOLOGIA}

Wywiad odgrywa kluczową rolę w badaniu neurootologicznym u osób dorosłych, jednak u małych dzieci polegamy głównie na obserwacjach rodziców lub opiekunów. W opinii autorów literatura dotycząca zawrotów głowy i zaburzeń równowagi będących następstwem uszkodzenia błędnika u dzieci jest uboga dlatego, że niezmiernie rzadko w praktyce otolaryngologicznej spotykamy się $\mathrm{z}$ pacjentem pediatrycznym opisującym takie dolegliwości. Dotyczy to nawet wyspecjalizowanych ośrodków otolaryngologii dziecięcej i pedoaudiologii. Nie ma również wiarygodnych danych dotyczących częstości występowania wrodzonych wad błędnika. Od kiedy wprowadzono w latach siedemdziesiątych XX w. do praktyki klinicznej obiektywne elektrofizjologiczne badania słuchu zauważono, że u około $9 \%$ dzieci z obustronną wrodzoną wadą słuchu rozwój motoryczny jest wyraźnie opóźniony. Z powodu jedności anatomicznej narządów słuchu i równowagi zasugerowano, że dysfunkcja ta jest związana z uszkodzeniem błędnika. Do takich wniosków doszli niezależnie Isabel Rapin - neurolog dziecięcy z Nowego Jorku, która przeprowadziła badania retrospektywne dokumentacji medycznej uczniów szkół dla niedosłyszących [10], oraz otolaryngolog z Tokio Kimitaka Kaga z zespołem. Neurologiczne objawy wrodzonych wad przedsionka zostały po raz pierwszy przedstawione na konferencji Towarzystwa Bárány’ego w 1980 roku [8].

W naszej poradni audiologicznej prowadzimy ponad 200 pacjentów z czuciowym niedosłuchem wrodzonym. W 2020 roku udało się przeprowadzić analizę dokumentacji i badania ankietowe pod kątem współwystępowania niedosłuchu z wadami narządu przedsionkowego, u 60 pacjentów z tej grupy. U 19\% badanych wystąpiło wyraźne opóźnienie rozwoju ruchowego i zaburzenia równowagi. U 7\% z tych niedosłyszących dzieci neurolog stwierdzał uszkodzenie ośrodkowego układu nerwowego. W grupie badanej przeważają chłopcy (37), nad dziewczętami (23). Badani mają wykonywane próby błędnikowe. Po zakończeniu badań i analizie statystycznej podzielimy się wynikami.

Wady ucha wewnętrznego mogą skutkować obniżeniem napięcia mięśniowego oraz opóźnieniem rozwoju motorycznego. Błędnik jest narządem receptorowym dla drogi przedsionkowo-rdzeniowej. Brak stymulacji przedsionkowej we wczesnych fazach rozwoju skutkuje obniżonym napięciem mięśni, głównie szyi i kończyn dolnych [11]. Dlatego też dzieci z wrodzoną wadą błędnika będą osiągać zdolność utrzymania głowy i podparcia kończyn dolnych wyraźnie później (Ryc. 1). Jednak w późniejszych etapach rozwoju dochodzi do ośrodkowej kompensacji napięcia mięśniowego $[12,13]$. W przypadku obustronnego porażenia przedsionka $\mathrm{z}$ reguły nie udaje się uzyskać pełnej kompensacji. Ludzie z wadą ucha wewnętrznego typu Mondiniego, w której błędnik ma kształt worka bez kanałów półkolistych, mają trudności z poruszaniem się w ciemności, późno uczą się jeździć na rowerze, próbę Romberga przy oczach zamkniętych mogą przez całe swoje życie wykonywać nieprawidłowo. Mogą 


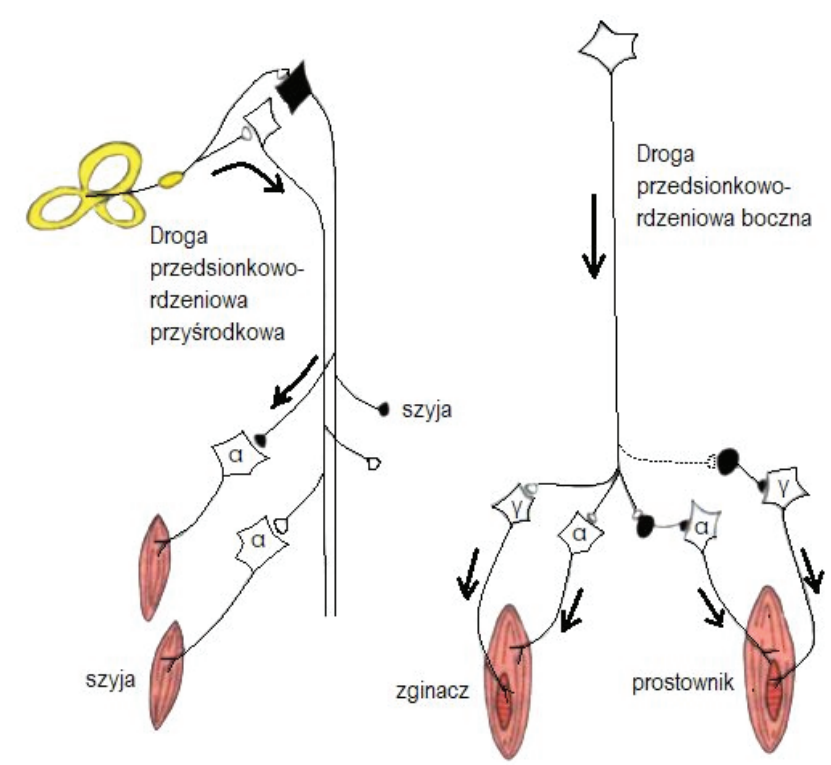

Ryc.1. Droga przedsionkowo-rdzeniowa. Po lewej: bodźce z kanałów półkolistych poprzez jądra przedsionkowe drogą przedsionkowo- rdzeniową przyśrodkową. Opóźnienie nabycia zdolności kontroli ruchów głową u dziecka z wadą ucha wewnętrznego można wiązać z dysfunkcją tego łuku odruchowego.

Po prawej: Zginacz pobudzany jest z kanałów półkolistych, poprzez jądra przedsionkowe drogą przedsionkowordzeniową boczną i neurony łączące d’ i У. Natomiast mięsień prostownik otrzymuje bodźce poprzez neurony hamujące oraz łączące à i y. Dysfunkcja tego łuku odruchowego powoduje, że dzieci z wrodzoną wadą błędnika zaczynają chodzić zdecydowanie później [13]

Fig.1. Vestibulospinal tract. Left: Neck muscles are controlled starting with the vestibular semicircular canals via the vestibular nucleus to the inner vestibulospinal tract. Stimuli from the vestibular semicircular canals through the vestibular nuclei via the medial vestibulospinal tract.

Delayed head and neck stability in a child with hearing loss is considered attributable to dysfunction of this neural circuit. Right: The flexor is triggered by the vestibular semicircular canals, via the vestibular nuclei, external vestibulospinal tract, and connector neurons $\dot{\alpha}$ and $\mathrm{y}$, whereas the extensor is triggered via suppression neurons and the connector neurons. Delayed walking in a child with vestibular loss is considered attributable to dysfunction of this neural circuit [13] mieć też duże trudności w nauce pływania z powodu braku orientacji w wodzie.

Jednym z podstawowych zadań układu przedsionkowego jest utrzymanie ostrości widzenia poprzez stabilizację obrazu na siatkówce w trakcie ruchów głowy. Jednakże dzieci z wrodzoną dysfunkcją błędników rzadko uskarżają się na zaburzenia widzenia. Nie opisują także objawów często obserwowanych u pacjentów dorosłych z nagłym uszkodzeniem błędnika, takich, jak skakanie lub zamazanie obrazu [13]. Wrodzona wada przedsionka skutkuje pogorszeniem ostrości dynamicznej wzroku, co prowadzi do upośledzenia kontroli wzrokowej w czasie ruchu, a także trudności w nauce czytania [14]. Z drugiej strony wrodzona ślepota prowadzi do opóźnionego rozwoju ruchowego z powodu braku efektora dla odruchu przedsionkowo-ocznego. W ten łuk odruchowy jest włączony kłaczek móżdżku, który u dzieci niewidomych nie może się prawidłowo rozwinąć $\mathrm{z}$ powodu braku stymulacji wzrokowej [12]. Nie jest pewne, czy dzieci niewidome zaczynają chodzić później z powodu braku bezpośredniej kontroli wzrokowej, braku odruchu przedsionkowo-ocznego, czy też opóźnionego rozwoju móżdżku. Kaga i wsp. wykazali zależność pomiędzy wrażliwością błędnika wyrażoną nasileniem reakcji oczopląsowej w próbie obrotowej, a wiekiem nabywania zdolności utrzymania głowy oraz wiekiem, w którym dziecko zaczyna chodzić bez podparcia. (tab. I.) [8]. Niedowłady i porażenia błędnika mogą prowadzić do upośledzenia zdolności poznawczych. W badaniach Lacroix i wsp. trzynastu około 10,5 letnich dzieci ze stwierdzonym deficytem czynności przedsionka, znamiennie gorsza w testach psychologicznych w porównaniu z grupą kontrolną były: wzrokowoprzestrzenna pamięć robocza, rotacja mentalna, oraz orientacja przestrzenna. Wyniki testów selektywnej uwagi wzrokowej nie różniły się istotnie między grupą badaną i kontrolną [15].

Przyczynami wtórnego nagłego uszkodzenia przedsionka u niemowląt i małych dzieci są najczęściej: działania uboczne antybiotyków aminoglikozydowych i zapalenie opon mózgowo rdzeniowych powikłane uszkodzeniem ucha wewnętrznego. W ostrej i podostrej fazie uszkodzenia najczęściej rozpoznawanym objawem jest ataksja, gdyż dochodzi wtedy do zaburzeń równowagi i obniżenia napięcia mięśniowego. Ataksja dotyczy zazwyczaj kończyn

Tab.I. Wiek nabywania zdolności: utrzymywania głowy, i samodzielnego chodzenia u dzieci głuchych z niedowładem lub porażeniem przedsionka wg. Kaga [13]

Tab.l. Age of acquiring the ability to hold the head up and walk independently in deaf children with paresis or atrial paralysis according to Kaga [13].

\begin{tabular}{|l|l|l|}
\hline $\begin{array}{l}\text { Reakcja oczopląsowa w próbie fotela } \\
\text { obrotowego } \\
\text { Nystagmus reaction in the rotational chair test }\end{array}$ & $\begin{array}{l}\text { Kontrola głowy } \\
\text { Head Control }\end{array}$ & $\begin{array}{l}\text { Samodzielny chód } \\
\text { Independent walk }\end{array}$ \\
\hline Prawidłowa Correct & $3-4 \mathrm{~m} . \dot{z}^{*}$ & $12-13 \mathrm{~m} . \dot{z}$. \\
\hline Uboga Poor & $4-6 \mathrm{~m} . \dot{z}$. & $18-24 \mathrm{~m} . \dot{z}$. \\
\hline Brak reakcji Without reaction & $6-7 \mathrm{~m} . \dot{z}$. & $24-30 \mathrm{~m} . \dot{z}$. \\
\hline
\end{tabular}

${ }^{*} \mathrm{~m} . \dot{z}$. - miesiąc życia (months old) 
dolnych. Jeśli do utraty czynności błędników dochodzi w wieku około 1 roku, występuje regresja nabytych wcześniej funkcji motorycznych na okres 1 do 4 miesięcy. Czas kompensacji znacznie się wydłuża jeżeli z dysfunkcją przedsionkową współistnieją inne choroby ośrodkowego układu nerwowego. Gdy u dotychczas prawidłowo rozwijającego się dziecka dojdzie do nagłej o utraty pobudliwości jednego z błędników w wieku 2 lat lub później, objawy deprywacji są krótkotrwałe. Kompensacja przedsionkowa u tak małych dzieci jest znacznie szybsza niż u dorosłych [13]. Diagnostyka różnicowa w postaci prób przedsionkowych u małych dzieci nie jest powszechnie dostępna, dlatego ostre zespoły przedsionkowe w tej grupie wiekowej są rozpoznawane tylko w wyjątkowych przypadkach. Dzieci w ostrej fazie choroby $\mathrm{z}$ objawami wegetatywnymi najczęściej hospitalizowane są w oddziałach pediatrycznych. $\mathrm{Z}$ powodu szybkiej rekonwalescencji, przyczyny dolegliwości upatruje się przeważnie w zatruciu pokarmowym lub infekcji wirusowej. Postawienie trafnej diagnozy w tych przypadkach jest trudne ponieważ oczopląs nie jest tak widoczny u niemowląt i małych dzieci jak u dzieci starszych czy dorosłych. U niemowląt przy nagłej jednostronnej deprywacji przedsionkowej oczopląs może nie występować wcale, zaś u małych dzieci jest wolniejszy i trwa krócej. Objaw ten, nawet gdy wystąpi, bywa maskowany przez objawy wegetatywne, które bardziej niepokoją opiekunów i lekarzy. Oczopląs niemowląt dostrzegalny w obserwacji bezpośredniej ma zwykle przyczyny w dysfunkcjach narządu wzroku, takich jak: zaćma wrodzona, hipoplazja nerwu wzrokowego czy dystrofie siatkówki. Nawet gdy jest jednym z objawów złożonych zespołów o podłożu genetycznym, w większości przypadków ujawnia się dopiero od 3 do 6 m.ż. [16].

\section{ZAWROTY GtOWY I ZABURZENIA RÓWNOWAGI U DZIECI A USZKODZENIA PRZEDSIONKA.}

W otolaryngologii tradycyjnie zajmujemy się diagnostyką przyczyn zawrotów głowy i zaburzeń równowagi związanych z uszkodzeniem układu przedsionkowego, jednakże wymienione objawy mogą mieć także przyczyny poza przedsionkowe. W naszej praktyce spotykamy od 10 do 20 dzieci rocznie skarżących się na powyższe dolegliwości, jednak uszkodzenie narządu przedsionkowego udaje się potwierdzić zazwyczaj u około $10 \%$ tych pacjentów. W badaniach O'Reilly i wsp. wykonanych w kilku amerykańskich ośrodkach, wśród konsultowanych w poradniach laryngologicznych 561151 dzieci, na szeroko pojęte zawroty głowy skarżyło się 2283 pacjentów, co stanowi około $0,4 \%$, jednak uszkodzenie narzą$\mathrm{du}$ równowagi stwierdzono zaledwie u $0,02 \%$. W grupie 268 dzieci z potwierdzonym uszkodzeniem obwodowym lub ośrodkowym narządu równowagi najczęstszym objawem były omdlenia, które zdarzały się 21 razy częściej niż w całej populacji pacjentów ORL. Niedosłuch czuciowy towarzyszył 43 razy częściej uszkodzeniu obwodowemu, zaś w grupie dzieci z uszkodzeniem ośrodkowym 16 razy częściej występowały bóle głowy [17]. W specjalistycznej klinice neurootologicznej w Osace z grupy 4349 pacjentów uskarżających się na napadowe zawroty głowy, obserwowanych na przestrzeni dekady, tylko 68 stanowiły dzieci w wieku poniżej 15 lat $(1,6 \%)$. Jedynie dwoje z tych 68 dzieci manifestowało oczopląs w czasie napadów zawrotów głowy (2,9\%). Były to czteroletnia dziewczynka z łagodnymi napadowymi zawrotami głowy ze zmiany położenia (Benign paroxysmal positional vertigo, BPPV) o charakterze cupulolithiasis kanału półkolistego bocznego, oraz jedenastoletni chłopiec z napadami migreny przedsionkowej [18]. W ciągu trzech lat w klinice narządu przedsionkowego przy szpitalu pediatrycznym w Bostonie diagnozowano 560 pacjentów - u 86 z nich $(15,4 \%)$ udało się zarejestrować oczopląs samoistny w badaniu wideonystagmografii. U około połowy dzieci był to oczopląs poziomy o ustalonym kierunku, W $3 / 4$ przypadków rejestrowany tylko po zniesieniu fiksacji wzroku. U $68 \%$ tych dzieci udało się rozpoznać choroby narządu przedsionkowego, najczęściej zapalenie neuronu przedsionkowego lub migrenę przedsionkową. U wszystkich 15 pacjentów z oczopląsem pionowym stwierdzono uszkodzenia ośrodkowego układu nerwowego [19]. W cytowanych przez brytyjski podręcznik neurologii dziecięcej Swaimana badaniach Humphriss i Hall, 5,7\% z 6965 badanych pod kątem zaburzeń równowagi 10 latków doświadczyło zawrotów głowy, opisywanych jako vertigo, czyli zawrotów z wrażeniem wirowego ruchu otoczenia. U prawie $1 / 5$ spośród tych dzieci zawroty miały charakter napadów występujących co najmniej $1 \mathrm{raz}$ w tygodniu. Autorki podają, że $31,5 \%$ z tych dzieci przerywało swoją aktywność z powodu złego samopoczucia. Najczęstszym objawem towarzyszącym zawrotom głowy były bóle głowy (około 60\%); 20\% tych dzieci doświadczało w czasie napadu sensacji słuchowych [20,21]. W Stanach Zjednoczonych w 2012 roku przeprowadzono populacyjne ankietowe badanie 10954 dzieci w wieku od 3 do 17 lat. Pytano w ankietach o wcześniejsze dolegliwości związane z bardzo szeroko pojętymi zawrotami głowy lub zaburzeniami równowagi. W badaniach pytano nie tylko o złudzenie ruchu (vertigo, dizziness), lecz także o okresową lub stałą niezdolność utrzymania równowagi, tendencję do upadków, upośledzoną koordynację ruchową. Pytania dotyczyły również doznań, które najczęściej nie mają związku z uszkodzeniami przedsionka, takich, jak uczucie oszołomienia, i ,pustki w głowie” (lightheadedness). Pytano również o bliżej niekreślone ,,inne zawroty głowy i zaburzenia równowagi”, gdzie ankieter nie będący wykształconym medykiem mógł umieścić wszystko, co mu się wydawało zawrotami głowy lub zaburzeniami równowagi. $\mathrm{Na}$ co najmniej jedno pytanie pozytywnie odpowiedziało 5,3\% ankietowanych, co świadczy że problem zawrotów głowy, zaburzeń równowagi i podobnych objawów dotyczyć może 3,3 miliona amerykańskich dzieci. Tylko 36\% respondentów tego badania, którzy doświadczyli dolegliwości, szukało pomocy medycznej [22].

W trzeciej edycji klasyfikacji międzynarodowego towarzystwa ds. bólów głowy (ICHD-3) znajdują się dwie jednostki chorobowe związane $\mathrm{z}$ dysfunkcją narządu przedsionkowego u dzieci [23]. Są to pojawiające się w wieku przedszkolnym łagodne napadowe zawroty głowy (Benign Paroxysmal Vertigo of the Childhood-BPVC) 
sklasyfikowane $\mathrm{w}$ pozycji 1.6.2., oraz sklasyfikowany w pozycji 1.6.3. ICHD-3 napadowy kręcz karku ( Benign Paroxysmal Torticollis of Infancy- BPTI). BPVC po raz pierwszy opisał Basser w 1964 roku. Choroba charakteryzuje się napadami zawrotów głowy typu vertigo, które trwają od kilkunastu sekund do kilku minut, z towarzyszącymi objawami wegetatywnymi i oczopląsem [24]. Napadowy kręcz karku (BPTI) został opisany po raz pierwszy przez Snydera w 1969 roku. Schorzenie to charakteryzują trwające minuty, godziny, a nawet dni napady skrętu głowy. Występuje ono u niemowląt i małych dzieci. Napadom mogą towarzyszyć objawy wegetatywne lub ataksja [25]. Powyższe schorzenia określa się mianem objawów związanych z migreną (Migraine Assotiated Symptoms, MAS). W każdym przypadku dochodzi do samoistnego wyleczenia. W obu schorzeniach badania neurologiczne oraz próby przedsionkowe wykonane między napadami nie wykazują zazwyczaj żadnych odchyleń od normy. BPVC i BPTI występują głównie u dzieci z rodzin, w których migrenę spotyka się znamiennie częściej. Brodsky i wsp. ukuli termin „marsz przedsionkowy”. Zauważyli oni, że u części niemowląt z BPTI pojawia się w wieku przedszkolnym BPVC, który w następnych latach życia może ujawnić się pod postacią migreny przedsionkowej lub innej $[26,27]$.

W 11 południowokoreańskich szpitalach przebadano retrospektywnie przyczyny zawrotów głowy i zaburzeń równowagi u 410 dzieci do 18 roku życia. Protokół badania składał się z całego szeregu prób przedsionkowych i słuchowych, oraz badania neurologicznego wraz z EEG i NMR OUN. W wybranych przypadkach wykonywano badania kardiologiczne lub psychiatryczne. W całej grupie najczęstszą przyczyną dolegliwości była migrena przedsionkowa (tab. II). W grupie dzieci przedszkolnych i szkolnych przeważały BPVC (tab. III, IV). W grupie nastolatków około 3/4 napadowych zawrotów głowy miało podłoże migrenowe (tab. V). Sztandarowa jednostka cho- robowa neurootologii - Choroba Mènièrè'a spotykana była tylko w grupie dzieci starszych, jednak częstość jej występowania była znacznie mniejsza niż u dorosłych [ 28].

\section{DIAGNOSTYKA}

\section{Wywiad.}

Choroby i dysfunkcje narządu przedsionkowego można podzielić ze względu na czas trwania dolegliwości na [29]

I. Krótkotrwałe epizody zawrotów głowy. Trwające od kilku sekund do minut. Można zaliczyć do nich:

1. Ortostatyczne zawroty głowy. Jeśli dolegliwości wystąpią zaraz po zmianie pozycji z leżącej lub siedzącej na pionową, to spowodowane są one najprawdopodobniej chwilowym deficytem krążenia na obszarze OUN lub wadą metaboliczną.

2. BPPV. Jeśli zawroty głowy z towarzyszącym im oczopląsem dwufazowym poziomym lub poziomo-obrotowym pojawiają przy zmianie pozycji głowy do określonego położenia, to mamy najprawdopodobniej do czynienia z przemieszczeniem się otolitów z łagiewki do kanałów półkolistych, czyli Łagodnymi Napadowymi Zawrotami Głowy ze Zmiany Położenia (Benign Paroxysmal Positional Vertigo, BPPV). U dzieci do przemieszczenia kamyczków otolitowych dochodzi najczęściej w czasie urazu głowy, zwykle migrują one do kanałów półkolistych bocznych lub tylnych. Wadę tę potwierdzamy oceniając oczopląs pojawiający się u chorego po wykonaniu manewrów diagnostycznych np. Dix Hallpike'a, „log roll” itp. W czasie badania pacjent powinien mieć zniesioną fiksację wzroku, szczególnie jeżeli badanie jest wykonywane w specjalnych goglach umożliwiających obserwację oczopląsu. Leczenie polega na odprowadzeniu kamyczków „na swoje miejsce" odpowiednimi manewrami.

Tab. II Przyczyny zawrotów głowy i zaburzeń równowagi u pacjentów do 18 roku życia wg. Lee i wsp.[28].

Tab. II. Cause of vestibular and balance disorders in total age group of children/patients up to 18 years old. Lee et al.[28]

\begin{tabular}{|l|l|}
\hline Rozpoznanie / Diagnosis & $\mathrm{N}(\%)$ \\
\hline Migrena przedsionkowa/ Vestibular migraine & $120(29,2)$ \\
\hline BPVC & $94(22,9)$ \\
\hline $\begin{array}{l}\text { Z układu krążenia ( ortostatyczne, naczyniowe) / Of the circulatory system (orthostatic, } \\
\text { vascular) }\end{array}$ & $38(9,2)$ \\
\hline Choroba Mènière'a/ Mènière's disease & $34(8,3)$ \\
\hline Psychogenne/ Psychogenic & $25(6,1)$ \\
\hline Zapalenie neuronu przedsionkowego/ Vestibular neuritis & $24(5,8)$ \\
\hline BPPV & $21(5,1)$ \\
\hline Złożone/Complex & $17(4,1)$ \\
\hline Inne/Other & $38(9,2)$ \\
\hline Ogółem/ Total & $411(100)$ \\
\hline
\end{tabular}

BPVC- Łagodne napadowe zawroty głowy wieku dziecięcego/ Benign paroxysmal vertigo of childhood

BPPV- Łagodne napadowe zawroty głowy ze zmiany położenia/ Benign paroxysmal positional Vertigo. 
Tab. III Rozkład przyczyn zawrotów głowy i zaburzeń równowagi u dzieci do 6 roku życia wg. Lee i wsp. [28].

Tab. III. Distribution of the causes of vestibular and balance disorders in preschool age group of children up to 6-years-old acc. to Lee et al.[28].

\begin{tabular}{|l|l|}
\hline Rozpoznanie / Diagnosis & $\mathrm{N}(\%)$ \\
\hline Migrena przedsionkowa/ Vestibular migraine & $6(19,4)$ \\
\hline BPVC & $22(70,9)$ \\
\hline Psychogenne/ Psychogenic & $1(3,2)$ \\
\hline BPPV & $1(3,2)$ \\
\hline Inne/Other (Ośrodkowe/ Central Origin ) & $1(3,2)$ \\
\hline Ogółem/ Total & $31(100)$ \\
\hline
\end{tabular}

BPVC- Łagodne napadowe zawroty głowy wieku dziecięcego/ Benign paroxysmal vertigo of childhood

BPPV- Łagodne napadowe zawroty głowy ze zmiany położenia/ Benign paroxysmal positional Vertigo.

Tab. IV Przyczyny zawrotów głowy u dzieci szkolnych ( 7 - 12 r. ż.) wg. Lee i wsp.[28]

Tab. IV. Distribution of vestibular and balance disorders causes in elementary school age group (between 7 and 12 -year-old). Lee et al.[28]

\begin{tabular}{|l|l|}
\hline Rozpoznanie / Diagnosis & $\mathrm{N}^{*}(\%)$ \\
\hline BPVC $^{* *}$ & $40(30,1)$ \\
\hline Migrena przedsionkowa/ Vestibular migraine & $39(29,3)$ \\
\hline Psychogenne/ Psychogenic & $8(6,0)$ \\
\hline BPPV*** & $6(4,5)$ \\
\hline Zapalenie neuronu przedsionkowego/ Vestibular neuritis & $6(4,5)$ \\
\hline Z układu krążenia ( ortostatyczne, naczyniowe) / Of the circulatory system (orthostatic, vascular) & $5(3,8)$ \\
\hline Złożone/Complex & $8(6,0)$ \\
\hline Inne/Other & $21(15,8)$ \\
\hline Ogótem/ Total & $133(100)$ \\
\hline
\end{tabular}

${ }^{*} \mathrm{~N}$ - liczba przypadków/ Number of cases

**BPVC- Łagodne napadowe zawroty gtowy wieku dziecięcego/ Benign paroxysmal vertigo of childhood

**BPPV- Łagodne napadowe zawroty głowy ze zmiany położenia/ Benign paroxysmal positional Vertigo.

Tab. V Przyczyny zawrotów głowy i zaburzeń równowagi młodzieży (13-18 r. ż,) wg. Lee i wsp.[28].

Tab. V. Distribution/ Cause of vestibular and balance disorders in adolescent group (between 13-and 18-years-old). Lee et. al.[28].

\begin{tabular}{|l|l|}
\hline Rozpoznanie / Diagnosis & $\mathrm{N}^{*}(\%)$ \\
\hline Migrena przedsionkowa/ Vestibular migraine & $75(30,4$ \\
\hline Choroba Mènière'a/ Mènière's disease & $34(13,8)$ \\
\hline $\begin{array}{l}\text { Z układu krążenia ( ortostatyczne, naczyniowe) / Of the circulatory system (orthostatic, } \\
\text { vascular) }\end{array}$ & $33(13,4)$ \\
\hline BPVC** & $33(12,9)$ \\
\hline Zapalenie neuronu przedsionkowego/ Vestibular neuritis & $16(6,5)$ \\
\hline BPPV** & $14(5,7)$ \\
\hline Złożone/Complex & $9(3,6)$ \\
\hline Inne/Other & $16(6,5)$ \\
\hline Ogółem/ Total & $247(100)$ \\
\hline
\end{tabular}

BPVC- Łagodne napadowe zawroty głowy wieku dziecięcego/ Benign paroxysmal vertigo of childhood BPPV- Łagodne napadowe zawroty głowy ze zmiany położenia/ Benign paroxysmal positional Vertigo.

II. Długotrwałe zawroty głowy trwające od jednej godziny do kilku dni.

1 Migrena przedsionkowa oraz związane $\mathrm{z}$ migreną BPVC są najczęstszą przyczyną zawrotów głowy w tej grupie. Napad migreny przedsionkowej polega na wystąpieniu silnych zawrotów głowy, najczęściej o typie wirowania. W czasie napadu może pojawić się oczopląs, światłowstręt i objawy wegetatywne. Aura napadu migreny 
przedsionkowej u dzieci występuje bardzo rzadko. Próby przedsionkowe oraz inne badania dodatkowe wykonane między napadami nie wskazują z reguły odchyleń od normy [27].

2. Choroba Mènière'a. Oprócz wyżej cytowanych badań koreańskich, autorom nie jest znany inny wiarygodny opis przypadku choroby Mènière'a u dziecka. Autorzy koreańscy nie podali w pracy dokładnych kryteriów rozpoznania tej choroby [28]. W naszej praktyce spotkaliśmy tylko jeden przypadek nastolatki, u której przed napadami zawrotów pomawiał się szum w jednym uchu, ale nie dochodziło do podwyższenia progu słuchu. Do dnia złożenia niniejszej pracy pacjentka ta miała tylko dwa napady. Na tej podstawie uważamy, że rozpoznanie choroby Mènière'a u dziecka należy traktować jako kazuistykę.

III. Przewlekłe zawroty głowy trwające od tygodni do miesięcy.

1.Zapalenie neuronu przedsionkowego (Neuronitis Vestibularis- NV) jest najczęstsza przyczyną zawrotów głowy. U dzieci NV jest w większości przypadków powikłaniem infekcji wirusowej. Zawroty głowy z oczopląsem i objawami wegetatywnymi występują tylko w początkowej, ostrej fazie choroby. U dzieci z reguły objawy ustępują szybciej niż u dorosłych. U młodzieży niepewność chodu i lęk przed upadkiem mogą utrzymywać się tygodniami. Nieprawidłowe wyniki próby dwukalorycznej czy testu Video Head Impulse (VHIT) potwierdzają rozpoznanie NV. U większości pacjentów próby przedsionkowe są prawidłowe już po około 1 miesiącu[29, 30].

2. Zapalenie ucha wewnętrznego (labirynthitis). Znacznie rzadziej występującą przyczyną przewlekłych zawrotów głowy jest Labirinthitis. Od NV odróżnia ją trwały niedosłuch po stronie uszkodzonego błędnika. Zawroty głowy występują do czasu zakończenia procesu kompensacji przedsionkowej, natomiast niedosłuch utrzymuje się zwykle do końca życia.

IV. Trwałe zawroty głowy czyli występujące latami.

1. Zaburzenia równowagi wywołane wzrokowo (Visually Induced Dizziness). Przyczyną tego schorzenia jest większa u dzieci zależność od wzroku w procesie utrzymania równowagi w czasie ruchu. Do utraty równowagi dochodzi m. in. w sytuacji gdy dziecko przemieszczając się na schodach ruchomych obserwuje poruszających się ludzi lub przedmioty lub gdy idąc obserwuje jadące $\mathrm{z}$ różnymi prędkościami samochody [31].

2. Przetrwałe zaburzenia równowagi (Persistent Perceptual Postural Dizziness- PPPD).

Jest to długotrwałe poczucie niestabilności i nawracających nieukładowych zawrotów głowy, które spełniają kryteria przyjęte w 2017r. przez Barany Society. PPD jest zaburzeniem funkcjonalnym i choć często występuje jako następstwo doznanych wcześniej chorób narządu przedsionkowego, uważa się, że jest to schorzenie odrębne zarówno od uszkodzeń układu równowagi, jak i zaburzeń psychiatrycznych [32].

3. Powyższe schorzenia wymagają różnicowania z kontrowersyjnym „Mal de Debarquement Syndrome”(MdDS). Jest to długotrwałe uczucie niestabilności, występujące najczęściej po długiej podróży statkiem, samolotem lub innymi środkami lokomocji[33].

PPD i MdDS spotykane są u nastolatków.

\section{Odrębności w badaniu przedmiotowym dzieci:}

Od lekarza otolaryngologa lub audiologa wymaga się, aby określił czy u podłoża dolegliwości podawanych przez pacjenta leży uszkodzenie błędnika. Ponieważ najmłodsze dzieci nie mają zdolności nazwania swoich dolegliwości, ważna jest obserwacja pacjenta i badanie fizykalne. Stosowane testy powinny być dostosowane do wieku i możliwości współpracy dziecka. Praktyka własna wskazuje, że powyżej 30 miesiąca życia do oceny równowagi można wykorzystać maksymalny czas, w jakim dziecko jest w stanie ustać na jednej nodze. Na podstawie obserwacji dzieci zdrowych i sprawnych ruchowo przyjęto, że zdrowy 30-miesięcy pacjent powinien już ustać co najmniej przez 1 sekundę, w wieku 36 miesięcy 2 sekundy, czterolatek 5 sekund, a sześcioletnie zdrowe dziecko co najmniej 10 sekund. Próby Romberga i Unterbergera można przeprowadzać już u dzieci 5 letnich. U dzieci przeprowadzana jest ponadto diagnostyka audiologiczna $\mathrm{z}$ oceną progu słuchu metodą audiometrii tonalnej. U najmłodszych dzieci, które są zdolne do współpracy wykonujemy rekonstrukcję audiogramu obiektywną metodą elektrofizjologiczną ASSR „CE chirp”( ryc. 2). U dzieci w drugim i trzecim roku życia słuch oceniamy także badaniami behawioralnymi, głównie audiometrią zabawową uwarunkowaną wzrokowo ( Visually Reinforcement Audiometry- VRA).

Ryc. 2. Rekonstrukcja audiogramu metodą ASSR "CE Chirp" u 6 miesięcznego dziecka z niedosłuchem lewostronnym czuciowo- nerwowym stopnia ciężkiego

Fig.2. Estimated audiogram of a six-month-old child using ASSR „CE Chirp." Severe sensorineural hearing loss in the left ear.

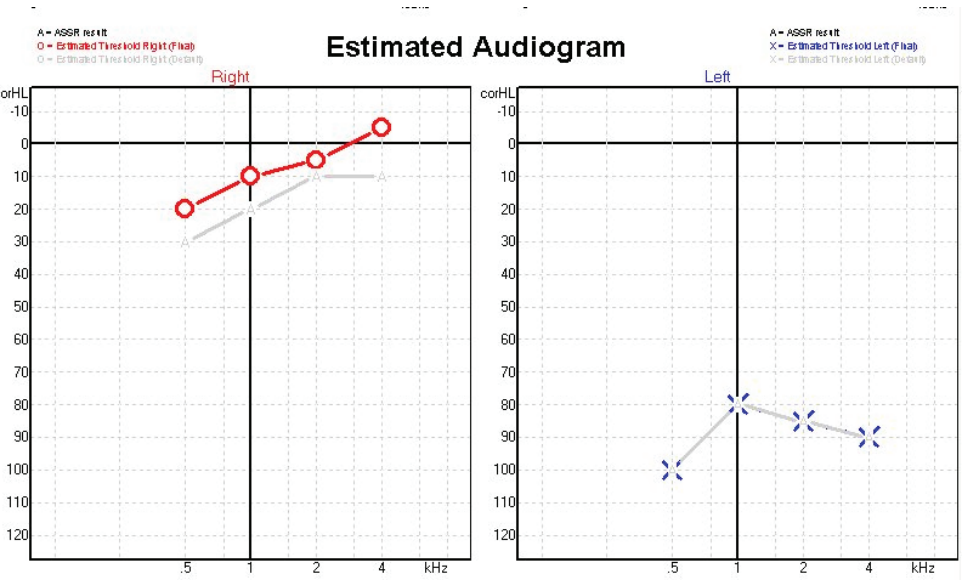

\section{Badania aparaturowe}

Istnieje szereg badań aparaturowych do oceny sprawności przedsionka. Do najbardziej podstawowych należą próba dwukaloryczna, testy obrotowe oraz test VHIT dla oceny odruchu przedsionkowo-ocznego, przedsionkowe potencjały wywołane dla oceny narządów otolitowych i nerwu przedsionkowego oraz badania posturografii dla obiektywizacji odruchów przedsionkowych [34]. 
Próba dwukaloryczna jest najpowszechniej stosowaną próbą błędnikową u dorosłych. Polega ona na naprzemiennym pobudzaniu obu przedsionków, bodźcami ciepłym i zimnym na zmianę, $\mathrm{z}$ rejestracją reakcji oczopląsowej będącej skutkiem pobudzenia termicznego przedsionków [35]. Stymulacja może polegać na podaniu wody lub wdmuchiwaniu powietrza do przewodu słuchowego zewnętrznego. Przypuszcza się, że stymulacja przedsionków bodźcem termicznym, u dorosłych z jednostronnym uszkodzeniem półkuli mózgu, może zmniejszyć objawy jednostronnego zaniedbania przestrzennego [36]. Dzieci lepiej tolerują bodziec termiczny kaloryczny niż wodny. Badanie to jest stosunkowo długotrwałe i wymaga współpracy pacjenta. Teoretycznie można wykonywać próbę dwukaloryczną od pojawienia się zdolności hamowania odruchu VOR czyli już po $6 \mathrm{~m}$. ż., jednak praktycznie rzadko udaje się ukończyć to badanie u dzieci młodszych niż 5 lat. Bardziej wiarygodne dane otrzymujemy korzystając z wideonystagmografii (VNG) niż elektronystagmografii (ENG) ze względu na częstsze występowanie komponenty obrotowej lub skośnej oczopląsu u dzieci. W badaniu VNG rejestracja za pomocą kamery na podczerwień umożliwia zapis rzeczywistych ruchu oka podczas gdy w ENG badany jest ruch w jednej płaszczyźnie zależnej od ułożenia elektrod.

Badaniem, które najwcześniej można wykonać u dzieci jest próba obrotowa. W badaniu tym można testować nawet niemowlę na kolanach matki siedzącej w fotelu Baraniego obracanym z odpowiednią prędkością kątową, na zmianę w obu kierunkach. U niemowląt i małych dzieci udaje się zwykle zapisać tylko oczopląs występujący w czasie obrotów. Oczopląs poobrotowy u najmłodszych pacjentów jest zwykle maskowany artefaktami spowodowanymi ruchem dziecka. Analizując zapis należy pamiętać, że u noworodków reakcja oczopląsowa jest śladowa. Częstotliwość oczopląsu podwaja się do końca 1. roku życia i potraja do końca 4. roku. U dorosłego częstotliwość oczopląsu jest czterokrotnie większa niż u rocznego dziecka. Czas trwania oczopląsu podczas jednostajnego ruchu obrotowego wydłuża się trzykrotnie do końca wieku niemowlęcego i aż sześciokrotnie do 6. r.ż. Czas trwania oczopląsu u dorosłego powinien wynosić około $40 \%$ czasu obserwowanego u sześciolatka. Reakcję oczopląsową możemy zarejestrować w próbie obrotowej nawet $\mathrm{u}$ chorych $\mathrm{z}$ wadą ucha wewnętrznego typu Mondiniego, czyli przy braku kanałów półkolistych. Świadczyć to o tym, że woreczek i łagiewka są także wrażliwe na zmiany prędkości kątowej [13]. Badania narządu przedsionkowego u dzieci próbami fotela obrotowego są coraz częściej wykonywane u dzieci. W naszej pracowni neurootologicznej wykonujemy je od listopada 2020 roku.

VHIT (video Head Impulse Test) jest badaniem instrumentalnym stosukowo dobrze tolerowanym przez małe dzieci. Do przeprowadzenia badania wymagane jest minimum współpracy. Pacjent powinien ufiksować wzrok w czasie badania. Dlatego z reguły nie testuje się VHIT niemowląt. Błędniki $\mathrm{w}$ tej próbie stymulowane najbardziej naturalnym bodźcem czyli ruchem głowy. Za pomocą VHIT porównujemy sprawność błędników prawego z lewym poprzez pomiar wartości odruchu przedsionkowo -ocznego (VOR), i rejestrację ruchów wyrównawczych oka, tzw. sakkad. W przeciwieństwie do badania fizykalnego instrumentalny VHIT pozwala na wykrycie sakkad ukrytych, czyli występujących w czasie ruchu głową. Natomiast badaniem fizykalnym możemy zaobserwować tylko te, które następują po zakończeniu poruszania głową (ryc. 3). U dzieci często odstępujemy od zalecanej odległości 1,5 m między okiem a obserwowanym punktem. Celem uzyskania fiksacji wzroku małego dziecka korzystamy np. z kolorowych zabawek. Badanie VHIT powinno się wykonywać w oddziałach ratunkowych, gdyż wykazuje bardzo wysoką specyficzność w różnicowaniu udarów od innych przyczyn ostrych obwodowych zawrotów głowy [37].

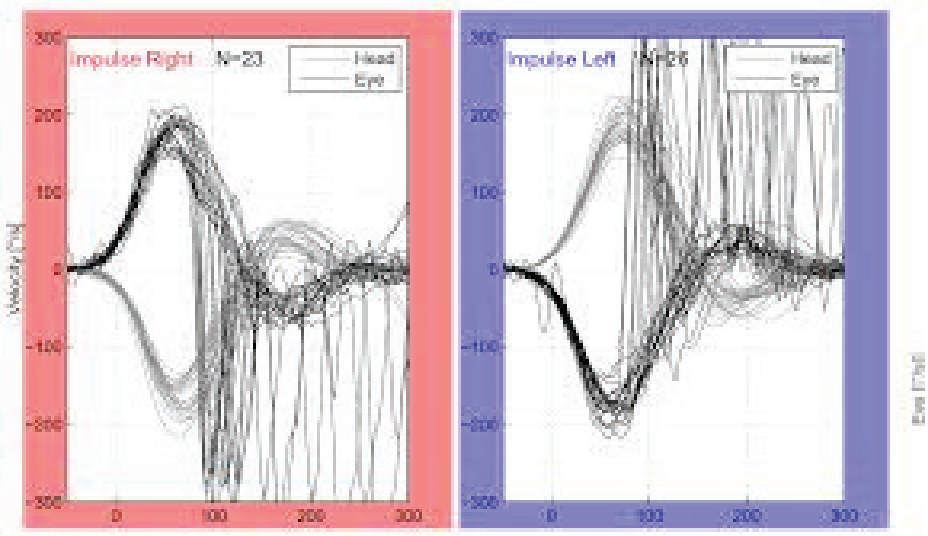

Ryc. 3. Test VHIT*- Sakkady gałki ocznej u dziecka z niedowładem prawego przedsionka.

Fig.3. VHIT*- Saccadic eye movements in a child with right ear vestibular loss.

VHIT*-Video Head Impuls Test ( brak polskiej nazwy).

Przedsionkowe potencjały miogenne (Vestibular Evoked Myogenic Potentials- VEMP) są to odpowiedzi dwufazowe o krótkiej latencji pojawiające się w skutek pobudzenia znajdujących się w błędniku woreczka i łagiewki. W badaniu tym wykorzystywana jest atawistyczna wrażliwość przedsionka na dźwięki. W naszej pracowni ucho stymulujemy bodźcem tonalnym, najczęściej o częstotliwości $500 \mathrm{~Hz}$ i natężeniu $95 \mathrm{~dB} \mathrm{HL}$, podawanym drogą powietrzną. Badając szyjne VEMP (cVEMP) sprawdzamy sprawność odruchu, który zaczyna się w woreczku. Bodźce są przewodzone głównie przez nerw przedsionkowy dolny, jądra przedsionkowe a następnie przez pęczek podłużny przyśrodkowy i dochodzą ipsilateralnie przez nerw dodatkowy do mięśnia mostkowo-obojczykowo-sutkowego bądź przez pęczek podłużny boczny do mięśnia czworobocznego. Oczne VEMP (oVEMP) powstają po stymulacji woreczka skąd bodziec poprzez nerw przedsionkowy górny jest przewodzony kontralateralnie do jąder ruchowych mięśnia skośnego dolnego gałki ocznej. Brakuje dowodów na użyteczność kliniczną VEMP w badaniach czynności woreczka lub łagiewki oraz różnicowaniu uszkodzeń nerwu przedsionkowego dolnego od górnego. Zarówno cVEMP jak i oVEMP wykazują jedynie dobrą czułość i specyficzność w diagnostyce przerwania ciągłości ścian kanału półkolistego tylnego [38]. U dzieci z wrodzonymi przetokami kanałów półkolistych dominującym objawem 
jest niedosłuch. Zaburzenia równowagi lub zawroty głowy występują u takich pacjentów tylko wyjątkowo.

W 2019 na uniwersytecie w Ghent w Belgii pojawiła się propozycja wykorzystania cVEMP do badań skriningowych narządu przedsionkowego. ,VIS - Flanders (Vestibular Infant Screening -Flanders)" proponuje się wykonywać u dzieci z wadą słuchu w 6 miesiącu życia. Uważamy, że protokół tego badania nie pozwala na dostateczną specyficzność aby test ten mógł być wprowadzony jako powszechny skryning narządu przedsionkowego u niedosłyszących niemowląt [39].

\section{Dyskusja}

Podstawowym problemem diagnostycznym u dzieci jest uzyskanie dokładnego wywiadu. Zarówno dane literaturowe, jak i obserwacje własne wskazują na powszechną u dzieci niezdolność jednoznacznego i zrozumiałego nazwania objawów podmiotowych określanych jako zawroty, w tym wrażenia wirowania otoczenia, uczucia popychania czy też usuwania się podłoża spod nóg, pełności lub pustki w głowie, dyskomfortu przestrzennego, wrażenia bliskiego omdleniu, itp. Bywa, że dzieci zawrotem nazywają uczucie lęku, a nawet ból głowy.

Odmienności dotyczą również badania przedmiotowego dzieci. Opisano powyżej różnice w nasileniu i amplitudzie oczopląsu, zarówno spontanicznego, jak i wywołanego w próbach błędnikowych u dzieci w zależności od wieku. Oczopląs samoistny u zdecydowanej większości dzieci ma charakter ukryty. Znaczy to, że można go wykryć tylko po zniesieniu fiksacji wzroku, czyli w całkowej ciemności. Detekcję oczopląsu przeprowadzamy zatem u dzieci metodami elektronystagmografii (ENG) lub wideony- stagmografii (VNG). Tylko w wyjątkowych przypadkach udaje się ukończyć VHIT u dzieci poniżej 3 roku życia, a próbę dwukaloryczną poniżej 5 r.ż. Przewagą wideonystagmografii jest możliwość rejestracji nie tylko poziomej, jak w przypadku ENG, ale także innych składowych oczopląsu: pionowej, skośnej, obrotowej itp. Występowanie u pacjenta oczopląsu pionowego, niezbornego, czy też innych, rzadkich postaci oczopląsu wymaga niezwłocznej diagnostyki obrazowej ośrodkowego układ nerwowego [19]. Symptomatologia wad wrodzonych przedsionka jest odmienna niż nabytych. Pierwotne porażenia i niedowłady błędnika mogą objawić się wyłącznie jako opóźnienie rozwoju ruchowego pacjenta (tab. I )[13].

Diagnostyka przedmiotowa dzieci zależy od wieku pacjenta. U niemowląt i małych dzieci podstawą jest badanie neurologiczne. Ze względu na częste współistnienie wad przedsionka i słuchu, dzieci z opóźnionym rozwojem ruchowym powinny być kierowane do audiologa posiadającego aparaturę dostosowaną do wieku dziecka celem badań narządu słuchu, i jeśli to możliwe, oceny stanu przedsionka próbami błędnikowymi. Diagnostyka neurootologiczna jest wskazana w przypadku podejrzenia chorób nabytych błędnika. Pytanie o konieczność diagnozowania niemowląt z podejrzeniem wrodzonego porażenia błędnika pozostaje otwarte. Zazwyczaj dopiero w wieku przedszkolnym możemy stwierdzić, że zaburzony rozwój ruchowy dziecka głuchego jest spowodowany równoczesnym uszkodzeniem ślimaka i przedsionka (ryc. 4). W tym przypadku dzieci są kierowane na rehabilitację $\mathrm{z}$ powodu rozpoznanego przez neurologa obniżonego napięcia mięśniowego i opóźnionego rozwoju psychomotorycznego. Taka rehabilitacja usprawnia także mechanizmy kompensacji przedsionko-
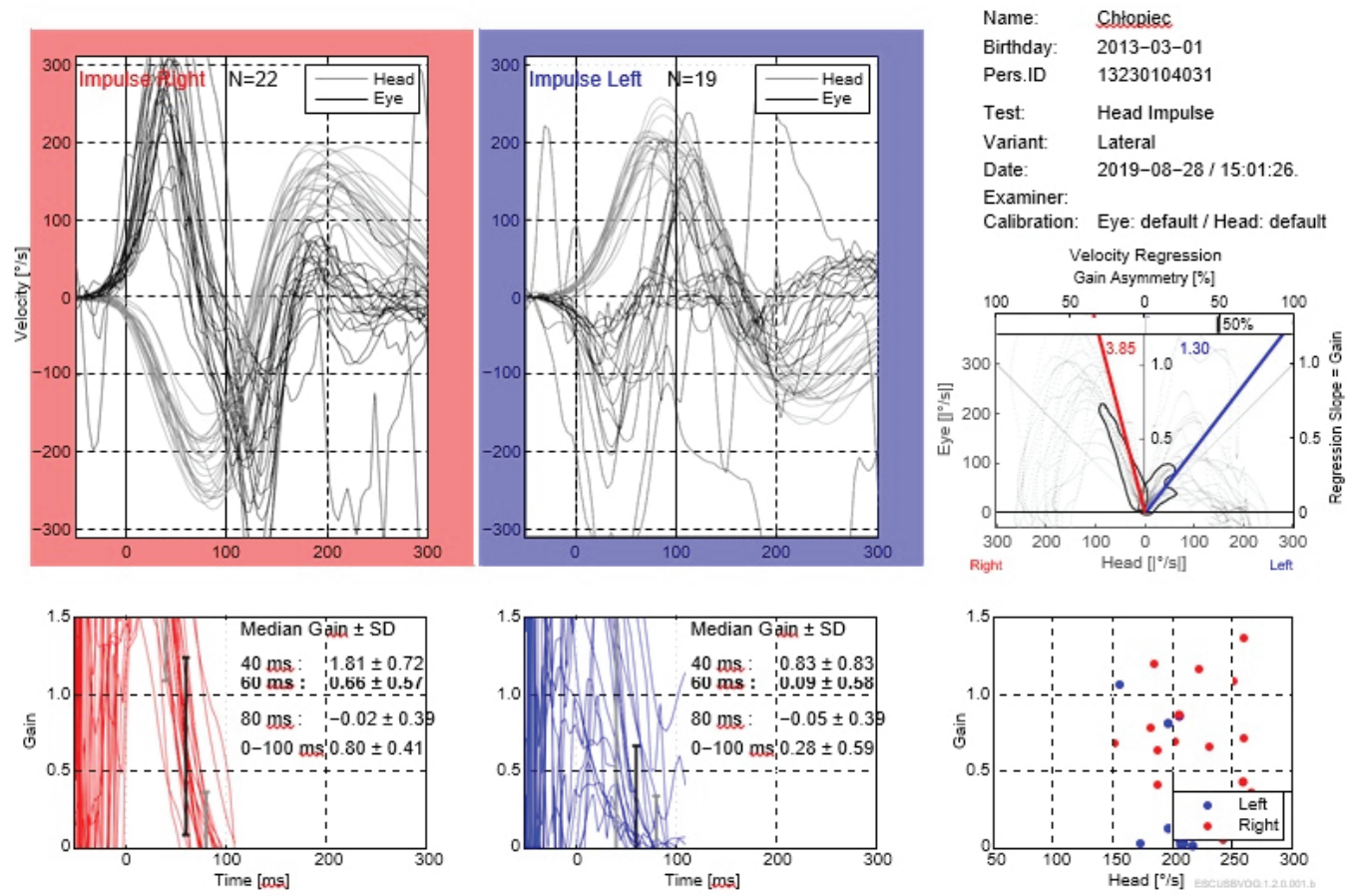

Ryc.4. Test VHIT* Pacjenta z wrodzonym obustronnym niedosłuchem stopnia głębokiego współistniejącym z niedowładem przedsionków. Chłopiec ten zaczynał samodzielnie chodzić około $30 \mathrm{~m}$. ż. ${ }^{* *}$

Fig.4. VHIT test. Patient with congenital bilateral hearing and vestibular loss. The Boy started to walking independently at the age of 30 months.

*VHIT- Video Head Impulse Test ( brak polskiej nazwy) ${ }^{* *}$ m. ż. - miesiąc życia 
wej. Wczesne rozpoznanie wad i uszkodzeń układu przedsionkowego pozwala także włączyć ćwiczenia stabilizujące spojrzenie, co jest istotne w dalszej nauce czytania [14].

W badaniach nad epidemiologią zawrotów głowy i zaburzeń równowagi u dzieci występują duże rozbieżności - od 0,4\% dzieci zgłaszających się do ośrodków otolaryngologicznych w badaniach O'Reilly i wsp. [17], do 5,7 \% dziesięciolatków przebadanych przez Hamphriss i Hall [21]. Różnice te zapewne są wynikiem odmiennej metodologii, oraz badanymi populacjami. Częstość występowania tych objawów będzie wyraźnie mniejsza, jeśli liczyć będziemy tylko tych, którzy szukają pomowcy lekarskiej. Natomiast skala problemu okaże się większa w przypadku badań ankietowych, szczególnie jeśli w ankiecie znajdą się pytania o dolegliwości nie mające związku z uszkodzeniami narządu przedsionkowego, takie jak dyskomfort przestrzenny, czy uczucie pustki w głowie [22]. Często rodzice lub opiekunowie odpowiadają pozytywnie na pytania w ankiecie bo mają zbyt wysokie oczekiwania co do sprawności swoich podopiecznych, a czasem, po prostu, mogą ulegać sugestii ukrytej w nieodpowiednio sformułowanym pytaniu. Hamphriss i Hall podają, że u około 30\% dzieci napady zawrotu głowy wymuszały przerwy w aktywności. Nasuwa się zatem pytanie; jaki to właściwie objaw występował u około 2/3 ankietowanych dzieci, które mimo napadów zawrotów głowy dalej kontynuowały zabawę czy też zajęcia szkolne? Objaw nazwany przez autorów artykułu ,vertigo” najwyraźniej nie mógł być następstwem dysfunkcji narządu przedsionkowego [21].

Nie należy nazywać zawrotami głowy objawów które nie wiążą się ze złudzeniem ruchu. Jeśli to możliwe, pacjent powinien opisać swoje dolegliwości nie używając pojęcia „zawroty głowy”. Spotykaliśmy już dzieci z rozpoznaniem wstępnym choroby błędnika, które były hospitalizowane i angażowały specjalistów z wielu dziedzin medycyny tylko z powodu trudności w zebraniu wywiadu. W prawie każdym z tych przypadków ostatecznie wykluczono chorobę ucha wewnętrznego. Najczęstszą przyczyną zawrotu głowy typu wirownia otoczenia (vertigo) u dzieci jest migrena przedsionkowa i zespoły związane z migreną $[17,22,28]$. Migreny przedsionkowej nie możemy traktować jako wady błędnika, ponieważ nawet w zaawansowanej i długo trwającej chorobie pomiędzy napadami wyniki prób błędnikowych mogą nie odbiegać od przyjętych norm. Zatem napad migreny przedsionkowej należy traktować jako czasową dysfunkcję odruchu przedsionkowo-ocznego. Jeśli wskutek powtarzających się napadów migrenowych dojdzie do trwałej dysfunkcji błędnika, co u dzieci zdarza się bardzo rzadko, to rozpoznać powinniśmy niedowład lub porażenie przedsionka. Jeśli schorzenie będzie mieć w dalszym ciągu charakter napadowy to być może powinniśmy rozpoznać w takim przypadku Chorobę Mènière'a, zwłaszcza gdy w czasie napadu lub bezpośrednio przed nim dochodzi do czasowego przesunięcia progu słuchu. W pracy Lee i wsp. choroba Mènière'a jest po migrenie drugą najczęstszą przyczyną zawrotów głowy u młodzieży, jednak autorzy publikacji nie podali kryteriów rozpoznania, jakimi się posługiwali [28]. Nie udało się nam znaleźć wiarygodnego opisu przypadku choroby Mènière'a u dziecka poniżej 15 r.ż., który spełniałby kryteria diagnostyczne Amerykańskiej Akademii Otolaryngologii [38].

Aktualnie nie ma możliwości oceny rozpowszechnienia trwałych uszkodzeń błędnika wrodzonych lub nabytych w pierwszym roku życia. Tzw. skryning przedsionkowy z Flanders pozostawia wiele do życzenia. Proponowany bodziec w(c)VEMP $59 \mathrm{~dB}$ HL dla $500 \mathrm{~Hz}$ jest za mało intensywny, i często u dzieci z wadą słuchu nie osiągnie on progu słyszenia, w związku z czym możemy nie uzyskać odpowiedzi. Zdecydowanie wyraźniejsze odpowiedzi w postaci fal P1 i N1 uzyskujemy przy skurczu czynnym mięśnia mostkowo -obojczykowo - sutkowego, niż biernym jak w proponowanym protokole ,VIS- Flanders”. Nie ulega wątpliwości że, powtarzalnego skurczu mięśnia u 6 miesięcznego pacjenta zwykle nie udaje się uzyskać. Także częste u dzieci w pierwszych latach życia zaburzenia przewodzeniowe słuchu powodują powstawanie zakłóceń, i przez to utrudniają wyróżnienie odpowiedzi z szumu tła. Uważamy, że powtarzalność takiego badania będzie niewielka, a czułość zbyt niska aby takie badanie mogłoby być wprowadzone jako powszechny skryning przedsionkowy niemowląt [39]. W naszym ośrodku od listopada 2020 wykonujemy badania przedsionków metoda fotela obrotowego z rejestracją reakcji oczopląsowej VNG. W badaniu tym można zachować odpowiednią powtarzalność bodźca. W związku z czym uważamy, że czułość i specyficzność tej próby byłaby wyższa niż, badań VEMP niemowląt. Po wykonaniu dostatecznej liczby badań podzielimy się doświadczeniami.

Zaproponowane w podręczniku Kliniczna Neurologia Dziecięca Fenichelsa różnicowanie przyczyn obwodowych od ośrodkowych zawrotów głowy, może mieć zastosowanie tylko w grupie pacjentów dorosłych i dzieci starszych. Audiometrii tonalnej czy błędnikowych prób cieplnych nie uda się wykonać u niemowląt i większości małych dzieci. Zaproponowane tam różnicowanie niedosłuchów przy użyciu prób nadprogowych objawu wyrównania głośności i testu zanikania tonu jest trudne nawet u pacjentów dorosłych. Próby te, naszym zdaniem, mają znaczenie historyczne. Najbardziej wiarygodnym badaniem różnicującym uszkodzenia ślimakowe od pozaślimakowych są obiektywne badania elektrofizjologiczne jak elektrokochleografia i badanie ABR z pomiarem latencji fal. Tab. VI [40].

Niemowlęta nie są wstanie poskarżyć się na zawroty głowy, a dominującym objawem wady błędnika będzie w tej grupie zaburzony rozwój motoryczny. Uszkodzenia nabyte u małych dzieci i pacjentów w wieku przedszkolnym zwykle pozostają niewykryte. Przyczyny tego należy upatrywać w znacznie szybszym wykształceniu kompensacji przedsionkowej w tym wieku niż u pacjentów starszych. Szybsza kompensacja przekłada się na krótsze utrzymywanie się objawów po nagłym wypadnięciu funkcji przedsionka u małego dziecka. W naszej praktyce do oceny czynności błędnika u dzieci w wieku przedszkolnym najczęściej są wykorzystywane próby fotela obrotowego oraz VHIT, a rzadziej testy cieplne dwukaloryczne z wideorejestracją oczopląsu (VNG). 
Tab. VI. Różnicowanie zawrotów głowy obwodowych od ośrodkowych [40] Tab. VI. Distinguishing Peripheral and Central Vertigo [40].

\begin{tabular}{|c|c|c|}
\hline Zawroty głowy/ Vertigo & Objawy/Symptoms & $\begin{array}{l}\text { Wyniki badań dodatkowych } \\
\text { Results of additional tests }\end{array}$ \\
\hline Obwodowe/ Peripheral & $\begin{array}{l}\text {-Mogą im towarzyszyć: niedosłuch, szum } \\
\text { uszny, ból ucha. } \\
\text {-W przypadku uszkodzenia jednostronnego } \\
\text { zbaczanie i padanie na stronę chorą. } \\
\text {-W uszkodzeniu obustronnym ataksja } \\
\text { pojawia się przy oczach zamkniętych. } \\
\text { Może występować oczopląs samoistny } \\
\text { lub położeniowy, }\end{array}$ & $\begin{array}{l}\text {-W przedsionkowych próbach cieplnych: } \\
\text { niedowład lub porażenie przedsionkowe, z lub bez } \\
\text { przewagi kierunkowej. } \\
\text {-Audiometria tonalnej często sugeruje niedosłuch } \\
\text { czuciowo- nerwowy. } \\
\text {-W audiometrycznych próbach nadprogowych: } \\
\text { * objaw wyrównania głośności w uszkodzeniach } \\
\text { ślimakowych. } \\
\text { *objaw zanikania tonu (Carharta) w } \\
\text { uszkodzeniach neurytycznych. }\end{array}$ \\
\hline Ośrodkowe/ Central & $\begin{array}{l}\text {-Często towarzyszą im dysfunkcje } \\
\text { móżdżku lub nerwów czaszkowych. } \\
\text {-Słuch jest zazwyczaj prawidłowy. } \\
\text {-Mogą z nimi współwystępować } \\
\text { zaburzenia świadomości. }\end{array}$ & $\begin{array}{l}\text {-Wyniki audiometrii tonalnej i słownej są } \\
\text { prawidłowe. } \\
\text {-Zaburzone bywa rozumienie konkurujących } \\
\text { wiadomości. } \\
\text {-W przedsionkowych próbach cieplnych może } \\
\text { występować przewaga kierunkowa, ale zawsze } \\
\text { przy symetrycznej pobudliwości błędników } \\
\text { - Potencjały wywołane z pnia mózgu, EEG, obrazy } \\
\text { CT oraz MRI mogą być nieprawidłowe. }\end{array}$ \\
\hline
\end{tabular}

Otwartym pozostawimy pytanie, czy warto wykonywać te nieprzyjemne dla dziecka w wieku niemowlęcym badania, skoro ich wyniki najczęściej nie mają znaczącego wpływu na leczenie? Próby błędnikowe wykonywane w pierwszych latach życia mają głównie charakter poznawczy i pozwalają lepiej zrozumieć patofizjologię odruchów przedsionkowych.

\section{Podsumowanie.}

Neurootologia to dyscyplina zajmująca się wadami, chorobami i innymi zaburzeniami narządu przedsionkowego czyli błędnika. Dysfunkcje błędnika z powodu ich złożonej manifestacji klinicznej w wieku rozwojowym leżą w obszarze zainteresowania dwóch specjalności lekarskich: otolaryngologii $\mathrm{z}$ audiologią oraz neurologii. Wrodzone i nabyte w pierwszym roku życia trwałe uszkodzenia tego narządu zaburzają rozwój sprawności motorycznych, czyli są przyczyną zaburzeń równowagi. Z powodu sąsiedztwa błędnika ze ślimakiem wadom tym nierzadko towarzyszy niedosłuch czuciowy lub głuchota. W pierwszych 2 latach życia próby błędnikowe nie są konieczne dla podjęcia właściwej decyzji terapeutycznej. Dzieci na zawroty głowy uskarżają się znamiennie rzadziej niż dorośli. Z powodu braku ścisłej definicji objawu ,zawrót głowy", a co za tym idzie braku możliwości badań porównawczych nie jest możliwa ocena skali zjawiska. Nie zawsze u podłoża objawu nazywanego przez pacjenta ,zawrotem głowy" leży dysfunkcja błędnika.

Podstawowym postępowaniem z chorym z porażeniem lub niedowładem pozostaje odpowiednia rehabilitacja.

\section{PIŚMIENNICTWO}

[1] Cumberworth V.E., Patel N.N., Rogers W., et al.: The maturation of balance in children. J Laryngol Otol., 2007; 121: 449-454.

[2] Flourens P.: Expèriencesur les canaux semi-circulaires des mammifère. Mew Acad Roy Sci, Publièdans Flourens, 1842; 9: 466-477.

[3] Ewald J.R.: Physiologishe Untersuchungenüberdans Endorgandes N. Octavus, Ergmann Wiesbaden 1892.

[4] Magnus R.: Körperstellung. Julius Springer, Berlin 1924.

[5] Andrè-Thomas A.H.: Dargassies S-A Etudes Neurologiques surle Nuveau -Nèet Jeune Nourrisson. Masson \& Cia, Paris 1952.

[6] Cohen B.,: Suzuki J.: Eye movements induced by ampullary nerve stimulation, Am J Phisiol 1963; 204: 347-351.

[7]Twitchell T.E.: Attitudinal reflexes. J Am Physiol 1965; 45: 411-518.

[8] Kaga K., Suzuki J., Marsh R.R., et al.: Influence of labyrinthine hypo activity on gross motor development in infants. Ann N Y Acad Sci. 1981; 374: 412-420.

[9] Ayres A.J.: Integration of sensation and learning disability., Kyodo Isho Shuppansha, Tokyo 1978.

[10] Rapin I.: Hypoactive labyrinths and motor development Clin Pediatr (Phila) 1974; 13: 922-937.

[11] Kaga K.: Vestibular compensation in infants and children with congenital and acquired vestibular loss in both ears. Int J Pediatr Otorhinolaryngol 1999; 20: 215-224.

[12] Ito M.: Blueprint of the brain. Chuo Koron, Tokyo 1980.

[13] Kaga K.: Vertigo and Balance Disorders in Children. Springer Japan, 2014.

[14] Rine R.M., Wiener-Vacher S.: Evaluation and treatment of vestibular dysfunction in children. Neurorehab 2013; 32: 507-518.

[15] Lacroix E., Edwards MG., De Volder M., et al.: Neuropsychological profiles in Children with vestibular loss. J Vest Res 2020; 30: 25-33.

[16] Penix K., Swanson M.W., De Carlo D.K.: Nystagmus in pediatric patients: interventions and patient-focused perspectives. Clin Ophthalmol 2015; 9: 1527-1536.

[17] O'Reilly R.C., Morlet T., Nicholas B.D., et al.: Prevalence of vestibular and balance disorders in children. Otol Neurotol 2010; 31: 1441-1444.

[18] Okumura T., Imai T., Higashi-Shingai K., et al.: Paroxysmal vertigo with nystagmus in children. Int J Pediatr Otorhinolaryngol 2016; 88: 89-93.

[19] Zhou G., Goutos C., Lipson S., et al.: Clinical significance of spontaneous nystagmus in pediatric patients. Int J Pediatr Otorhinolaryngol 2018; 111: 103-107.

[20] Furman J.M., Goldstein A.: Vertigo. [in:] Swaiman's Pediatric Neurology (Sixth Edition), Elsevier,2017. 
[21] Humphriss R,L., Hall A.J.: Dizziness in 10 year old children: an epidemiological study. Int J Pediatr Otorhinolaryngol 2011; 75: 395-400.

[22] Li C.M., Hoffman H.J., Ward B.K., et al.: Epidemiology of Dizziness and Balance Problems in Children in the United States: A PopulationBased Study. J Pediatr 2016; 171: 240-247.

[23] International Headache Society Classification Subcommittee. The international classification of headache disorders, 3rd edition (beta version). Cephalalgia. 2013; 3: 629-808.

[24] Basser L.S.: Benign Paroxysmal Vertigo of Childhood. Brain 1964; 87: 141-152.

[25] Snyder L.H.: Paroxysmal Torticollis in Infancy. Am. Dis. Child 1969; 117: 458- 460.

[26] Brodsky J., Kaurac K., Shoshany T., et al.: Benign paroxysmal migraine variants of infancy and childhood: Transitions and clinical features. Eur $\mathrm{J}$ Pediatr Neurol 2018; 22: 667-673.

[27] Lempert T., Olesen J., Furman J., et al.: Vestibular migraine: diagnostic criteria. J Vestib Res 2012; 22: 167-172.

[28] Lee J.D., Kim C.H., Hong S.M., et al.: Prevalence of vestibular and balance disorders in children and adolescents according to age: A multi-center study. Int J Pediatr Otorhinolaryngol 2017; 94: 36-39.

[29] Śpiewak P.: Zawroty głowy u dzieci. Epidemiologia, symptomatologia i diagnostyka. XXI Dni Otolaryngologii Dziecięcej. Poznań 9-11 Maj 2019.

[30] Hain T.C.: VHIT test. April 27 2020. Address: https://www.dizziness-and balance.com/testing/VHIT/vhit.html.

[31] Pavlou M., Whitney S.L., Alkathiry A.A., et al.: Visually Induced Dizziness in Children and Validation of the Pediatric Visually Induced Dizziness Questionnaire. Front Neurol 2017; 8: 656.

[32] Staab J.P., Eckhardt-Hennb A., Horiic A., et al.: Diagnostic criteria for persistent postural-perceptual dizziness (PPPD): Consensus document of the committee for the Classification of Vestibular Disorders of the Barany Society. J Vest Res 2017; 27: 191-208.
[33] Dai M., Cohen B., Cho C., et al.: Treatment of the Mal de Debarquement Syndrome: A 1-Year Follow-up. Front Neurol. 2017; 8: 175.

[34] Orendorz -Frączkowska K., Kubacka M.: Rozwój kontroli posturalnej u dzieci zdrowych od 6 do 17 roku życia. Cześćć I Ocena kontroli posturalnej w teście badania klinicznego interakcji sensorycznej w równowadze( mCTSIB) u dzieci w wieku 6- 7 lat. Otolaryngol Pol 2020; 74: 29-35.

[35] Janczewski G., Bień S.,: Testy cieplne [w:] Otoneurologia T. I Janczewski G. [ed.] BEL CORP, Warszawa 1998.

[36] Hole J., Reilly K.T., Nash S., et al.: Caloric Vestibular Stimulation Reduces the Directional Bias in Representational Neglect. Brain Sci 2020; 10: 326.

[37] Śpiewak P.: Zastosowanie testu VHIT w ambulatoryjnej diagnostyce klinicznej - doświadczania własne. Otorynolaryngologia- XIV Konferencja Naukowo Szkoleniowa, oraz IX Konferencja Polskiego Towarzystwa Audiologicznego i Foniatrycznego, Łódź 2-3 Marca 2017.

[38] Fife T.D., Colebatch J.G., Kerber K.A, et al.: Practice guideline: Cervical and ocular vestibular evoked myogenic potential testing: Report of the Guideline Development, Dissemination, and Implementation Subcommittee of the American Academy of Neurology. Bailliers Clin Neurol 2017: 89: 2288-2296.

[38] Goebel J.A.: 2015 Equilibrium Committee Amendment to the 1995 AAOHNS Guidelines for the Definition of Ménière's Disease. Otolaryngol Head Neck Surg 2016; 154: 403-404.

[39] Martens S., Dhooge I., Dhondt C., et al.: Vestibular Infant Screening Flanders: The implementation of a standard vestibular screening protocol for hearing -impaired children in Flanders. Int J Pediatr Otorhinolaryngol 2019; 120: 196-201.

[40] Piña-Garza E.J., James K.C,: Vertigo. [in:] Fenichel's Clinical Pediatric Neurology. A Signs and Symptoms Approach. (Eight edition) Elsevier 2019.

\section{Adres do korespondencji:}

Przemysław Śpiewak NZOZ Audiofonika Sp.J. 43-316 Bielsko- Biała ul. Karpacka 46

email: przemyslaw.spiewak@gmail.com 